\title{
Flower and fruit production and insect pollination of the endangered Chilean tree, Gomortega keule in native forest, exotic pine plantation and agricultural environments
}

\author{
Producción de flores y frutas y polinización por insectos de Gomortega keule en bosque \\ nativo y en terrenos agrícolas, un árbol chileno en peligro de extinción
}

TONYA A. LANDER ${ }^{1, *}$, STEPHEN A. HARRIS $^{1} \&$ DAVID H. BOSHIER ${ }^{1}$

${ }^{1}$ Department of Plant Sciences, University of Oxford, South Parks Road, Oxford OX1 3RB UK
* Corresponding author: tonya.lander@plants.ox.ac.uk

\begin{abstract}
This study was undertaken to discover whether patterns of flower and fruit production for Gomortega keule, an endangered Chilean tree, differ between exotic pine plantation, agricultural and native forest environments. A pilot study was also undertaken to identify the primary pollinators of G. keule. Although similar proportions of G. keule trees flowered in the agricultural and native forest areas, more trees in the agricultural sites produced fruit compared to trees in the native forest sites. Flowering and fruiting of $G$. keule was extremely rare in the exotic pine plantations. Our data show that $G$. keule flowers are predominantly visited by syrphid flies in March-April, and that syrphids carry a greater proportion of $G$. keule pollen than the other insects collected. Native forest and low intensity agricultural systems appear to provide habitat in which syrphids forage and G. keule is able to produce fruit successfully, but exotic pine plantation does not; suggesting that a landscape made up of a mosaic of different landuse types is not necessarily inimical to the continued reproduction of $G$. keule, but that the combination and types of landuses and intensity of management must be carefully considered.
\end{abstract}

Key words: Chile, Gomortega, landuse, pollination, Syrphid.

\section{RESUMEN}

El presente estudio fue realizado con el objetivo de establecer si los patrones de producción de flores y frutos de Gomortega keule (Gomortegaceae), un árbol chileno en peligro de extinción, son diferentes entre áreas de plantaciones de pinos exóticos, terrenos agrícolas y áreas de bosque nativo. También fue llevado a cabo un estudio piloto para identificar los principales polinizadores de G. keule. A pesar de que en tierras agrícolas y en áreas de bosque nativo floreció una proporción similar de árboles de G. keule, en zonas agrícolas fructificó una mayor proporción en comparación con los árboles de áreas de bosque nativo. La floración y fructificación de $G$. keule fue extremadamente rara en las areas de plantaciones de pinos exóticos. Nuestros datos indican que las flores de G. keule son visitadas predominantemente por sírfidos durante marzo y abril, y que dichos sírfidos transportan una mayor proporción de polen de G. keule que cualquier otro insecto recolectado. El bosque nativo y los sistemas agrícolas no intensivos parecen proporcionar a los sírfidos un hábitat en el cual alimentarse y donde G. keule es capaz de fructificar, lo cual no sucede en las plantaciones de pinos exóticos. Esto sugiere que un paisaje compuesto por un mosaico de diferentes tipos de uso del suelo no es necesariamente hostil para la reproducción continua de G. keule, pero que la combinación y tipos de uso del suelo e intensidad de su manejo deben ser consideradas cuidadosamente.

Palabras clave: Chile, Gomortega, polinización, sírfidos, uso del suelo. 


\section{INTRODUCTION}

Landuse change and associated habitat fragmentation have been shown to reduce population sizes, increase local extinction risk, change patterns of geneflow, migration and establishment, and change interspecific interactions (Murphy \& Lovett-Doust 2004, Jules \& Shahani 2003, Bawa \& Seidler 1998). This fragmentation of native habitats is widely recognised as one of the most important threats to the survival of species, particularly rare and endangered species (Lavergne et al. 2005, Adriaensen et al. 2003). To identify and quantify the impacts of landscape change, particularly changes in reproductive success in rare species, it is necessary to understand a species' reproductive biology, including any biotic pollinators.
This study was undertaken to discover whether patterns of flowering and fruiting for Gomortega keule Ruíz \& Pavón, an endangered Chilean tree (Oldfield et al. 1998), differ between exotic pine plantation, agricultural and native forest environments. To our knowledge, neither flower and fruit production nor pollination have previously been studied in $G$. keule, although Renner et al. (1997) predicted it would be pollinated by small flies or bees, based on the size and shape of the flowers. Therefore a pilot study was also undertaken to identify the primary pollinators of G. keule in the study area.

$G$. keule is a diploid $(2 \mathrm{n}=42)$ tree in the monotypic family Gomortegaceae, order Laurales (Fig. 1) (Soltis \& Soltis 2004, Zanis et al. 2003, Oldfield et al. 1998, Goldblatt 1976 ). The global distribution of the species is limited

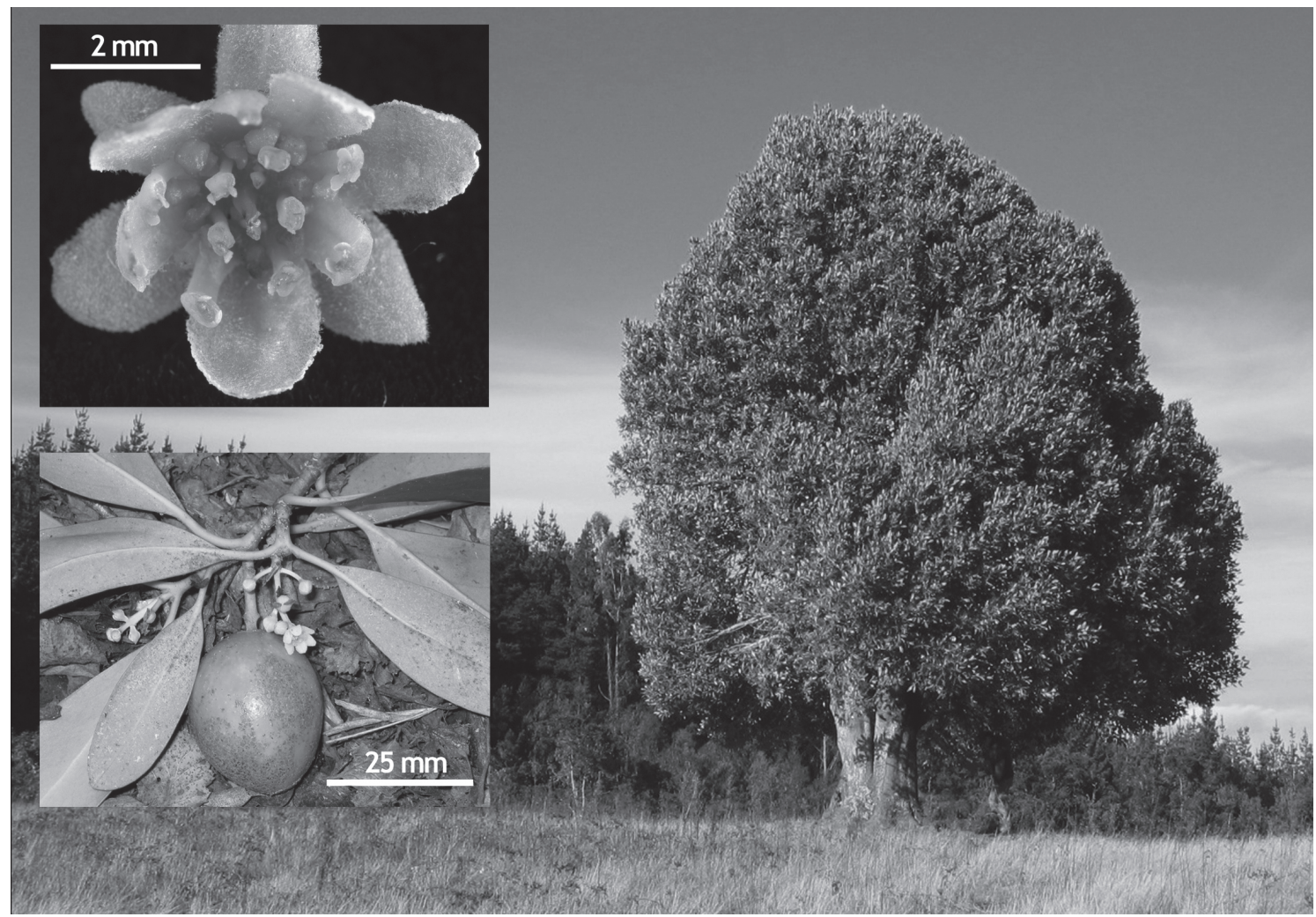

Fig 1: Gomortega keule is an evergreen tree from central Chile that may reach $30 \mathrm{~m}$ tall. It produces small, white, protogynous flowers; a flower in the male phase of protogynous maturation is shown with displayed anthers (inset top). The fruit is a yellow drupe, shown here unripe with leaves, flowers and flower buds (inset bottom). Flower photo by John Baker.

Gomortega keule es un árbol de hojas perennes del Chile central que puede alcanzar $30 \mathrm{~m}$ de altura. Produce flores pequeñas, blancas y protóginas; una flor en fase masculina de la maduración protóginas se muestra con sus anteras expuestas en el recuadro superior. El fruto es una drupa amarilla, en el espécimen fotografiado se muestra el fruto inmaduro junto a flores y capullos florales (recuadro inferior). Foto de la flor de John Baker. 
to an area $70 \mathrm{~km}$ wide and $250 \mathrm{~km}$ long, stretching from a southern point near Concepción, Chile (Lat/Long 37.3 S, 73.4 W), north to near Constitución (35.6 S, 72.4 W) (San Martin \& Sanchez 1999) in the Central Chile Biodiversity Hotspot (Myers 1990). This study was undertaken in the centre of the species' distribution, at the border between the Maule and Biobío Regions. Forest clearance for plantations and agriculture has reduced the area of native forest in this region (Bustamante et al. 2005, FAO 2005, San Martín \& Donoso 1995), and created a complex mosaic of landuse types, including small patches of native forest containing populations of $G$. keule. These native forest patches are surrounded by other landuses, primarily exotic pine (Pinus radiata D. Don) and eucalyptus plantations and agriculture, within which G. keule also exists in small groups or as single individuals.

\section{METHODS}

\section{G. keule flowering and fruiting}

Twenty-six study sites were identified in the Tregualemu area on the border between the Maule and Biobío Regions of Chile (Fig. 2). These study sites contain 498 G. keule trees, which is all the individuals that were found during two intensive field surveys (FebruaryApril 2005 and July-August 2006). The largest population in this study, 176 individuals, is in the Reserva Nacional Los Queules, a 145 ha reserve in southern Maule dedicated to the

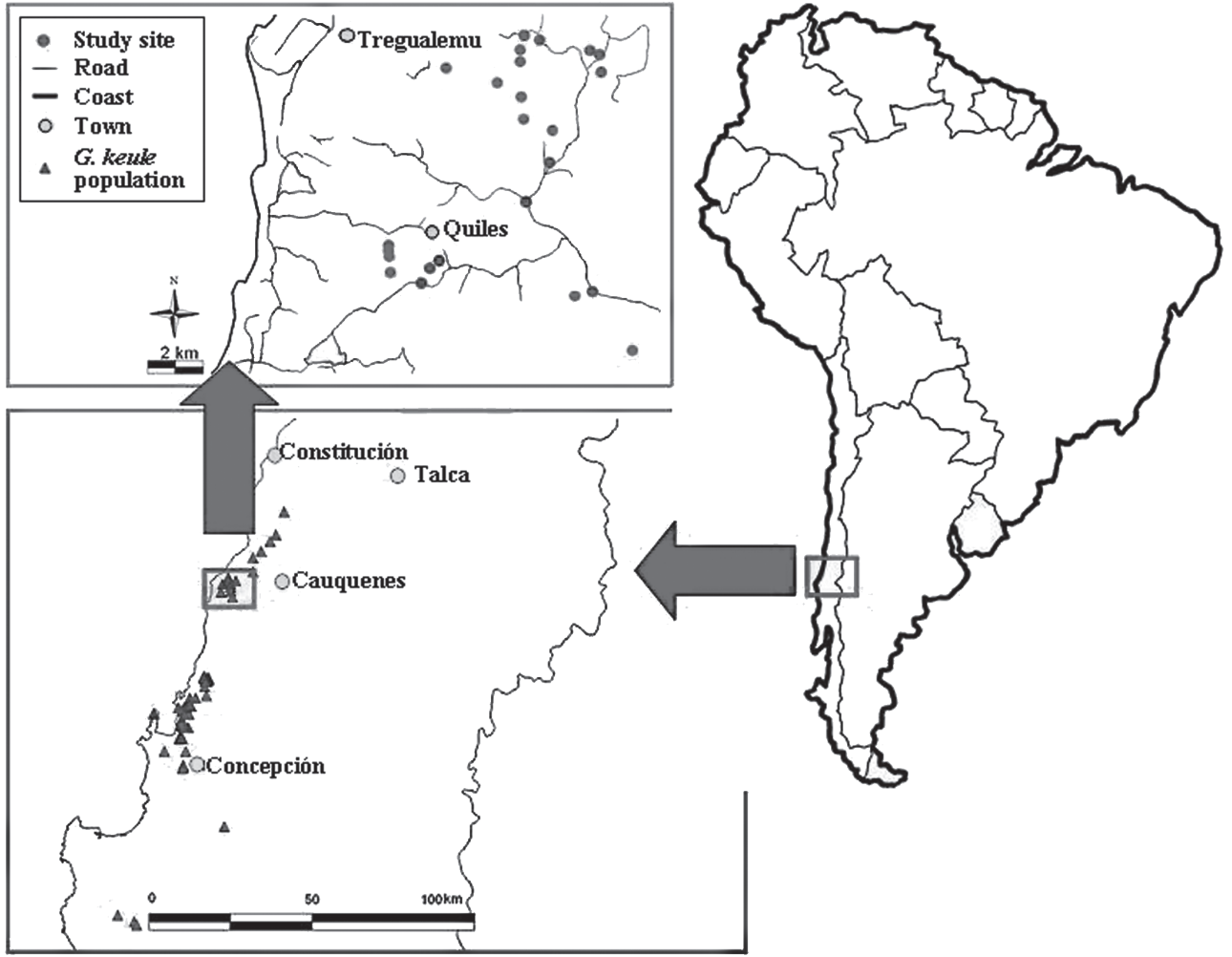

Fig 2: The rectangle on the map of South America (right) shows the global distribution area of Gomortega keule (Maule and Biobío Regions, Chile). The triangles on the map of central Chile (bottom left) represent the known populations of G. keule (Hechenleitner et al. 2005); the rectangle indicates the study area. The study area map (top left) shows the centre points of the 26 study sites and local roads. Tregualemu in the top left map is located at Lat / Long: $35^{\circ} 56^{\prime} \mathrm{S} / 72^{\circ} 43^{\prime} \mathrm{W}$.

El rectángulo en el mapa de América del sur (derecha) muestra la distribución global de Gomortega keule (regiones Maule y Biobío, Chile). Los triángulos en el mapa de Chile central (recuadro inferior) representan las poblaciones conocidas de $G$. keule (Hechenleitner et al. 2005); el rectángulo indica el área de estudio. El mapa del área de estudio (recuadro superior) muestra los puntos centrales de los 26 sitios del estudio y los caminos locales. Tregualemu en el recuadro superior se localiza a Lat / Long: $35^{\circ} 56^{\prime} \mathrm{S} / 72^{\circ} 43^{\prime} \mathrm{O}$. 
conservation of $G$. keule. The smallest 'populations' are single trees outside of native forest and separated by more than $200 \mathrm{~m}$ from other G. keule individuals. Ten of the G. keule populations were within areas of native forest ( $\mathrm{n}=388$ trees), nine were in agricultural areas $(\mathrm{n}=44$ trees) and seven were inside pine plantations $(\mathrm{n}=66$ trees $)$.

Flowering status was assessed with binoculars for all trees, although those trees with canopies either too high or so surrounded by other tree canopies that they could not be assessed with confidence were only categorized as either ( $\mathrm{Y}$ ) flowers present or $(\mathrm{N})$ not possible to assess. Those trees it was possible to assess were categorized as (1) flowers absent, (2) 1-10 flowers, (3) 11-100 flowers, or (4) more than 100 flowers. The chi-square test was used to test the difference between the proportion of trees in each of the 4 flowering categories in the native forest and agricultural environments. Previous authors have observed that G. keule flowers throughout March and April (Rodríguez \& Quezada 2001) and for this study flowering status of the trees was recorded during those two months. However our field observations suggest flowering occurs from March to June and therefore our field data only reflects flowering status during half of the flowering season. Importantly this species appears to fit the steady state syndrome of species that produce few flowers but continue to flower for many days (Gentry 1974), suggesting that the flowering pattern will be similar through the flowering season.

G. keule fruits are large (approximately $5 \mathrm{x}$ $5 \mathrm{~cm}$ (Hechenleitner et al. 2005)) and yellow and easily seen with binoculars, so it was possible to categorize fruit production for all trees as either present or absent. The student's t-test was used to compare trees fruiting and not fruiting in the two environments. During field observation it was found that the fruit remain on the tree for one year, so fruit and flowers are present simultaneously on the tree but the fruit present in a given year represent the results of flowering from the previous year. This characteristic makes it impossible to assess reproductive success in terms of proportion of flowers that become mature fruit without several years of data. It is, however, possible to simultaneously compare the proportion of the population that is flowering or fruiting in the different environments.

\section{Insect sampling}

Between 28 $8^{\text {th }}$ March and $2^{\text {nd }}$ April 200516 person-hours were spent trapping insects in the Tregualemu area of Maule Region, Chile. Seven Gomortega keule trees at five sites were used as sampling locations; four in native forest and three on agricultural land under low intensity management (Table 1). As the $G$. keule trees inside the exotic pine plantation showed extremely low levels of fruiting and flowering (see Results) the decision was made not to conduct pollinator surveys in this environment. For this pilot study two insect sample heights were used. One person standing on the ground sampled at between 1 and $3 \mathrm{~m}$ above the ground and one person standing on a ladder sampled at between 3 and $5 \mathrm{~m}$ above the ground. Capture of flower visitors followed by identification and quantification of pollen on their bodies is a common technique for

TABLE 1

Insects were sampled on Gomortega keule trees at five study sites, three in agricultural land and two in native forest in the Maule region of Chile.

Los insectos fueron recolectados en árboles de Gomortega keule en cinco localidades, tres de ellas situadas en tierras de cultivo y dos en bosques nativos en la región de Maule, Chile.

\begin{tabular}{|c|c|c|c|c|}
\hline Site & Environment & Latitude & Longitude & $\overline{\text { Altitude }(\mathrm{m})}$ \\
\hline Ralbun & Native Forest & -36.06 & -72.64 & 525 \\
\hline Soltero 0126 & Native Forest & -35.98 & -72.68 & 475 \\
\hline Quiles Alto & Agriculture & -36.04 & -72.71 & 375 \\
\hline Ramadillos & Agriculture & -36.01 & -72.67 & 550 \\
\hline Soltero 0262 & Agriculture & -36.02 & -72.68 & 475 \\
\hline
\end{tabular}


identification of pollinators (Sakai \& Inoue 1999, House 1989), thus insects landing on the flowers of G. keule were collected with a handheld net and put directly into individual vials with $70 \%$ alcohol. The specimens from the field were then transported to the laboratory, where each insect was removed from the first vial of alcohol and placed in a new vial with 95 $\%$ alcohol. The alcohol from the first vial was spun in a Boeco M-24 centrifuge ( $86 \mathrm{~mm}$ rotor) at 2,500 rpm for 10 minutes. A slide was prepared using the pellet from the vial mixed with glycerol jelly and safranine dye according to the Wodehouse (1935) technique, and was viewed on a Leica DMR microscope at 40X magnification. All pollen grains on the slide were counted and classified into one of four categories: the three most common species; Gomortega keule, Gevuina avellana Molina (Proteaceae) and Pinus spp. (Pinaceae), and all other species ('other'). The student's t-test was used to compare the number and proportion of pollen grains in the two environments.

Insects were identified by Dr. Stephen D. Gaimari (California Department of Food and Agriculture; Lauxaniidae, Accession: 13\&30/ T.Lander 2008/Ph.D. dissertation, National Museum of Natural History, Washington, DC, USA), Dr. James Hogan (University of Oxford Natural History Museum; Colletidae, Sphecidae, Vespidae, Accession: OUMNH2008-077), Dr. Tim New (La Tribe University; Australia, Psocidae, Accession: OUMNH-2008077), and Dr. F. Christian Thompson (Systematic Entomology Lab USDA; Syrphidae, Accession: Systematic Entomology Lab, USDA, Smithsonian Institution, Washington, DC).

\section{RESULTS}

\section{G. keule flowering and fruiting}

Difficulty in assessing flowering status on tall trees and in the dense forest canopy meant that of the 388 trees in native forest sites, $34 \%$ (130 trees) could be assessed with confidence. Of these 130 trees $35 \%$ had no flowers (category 1 ), $22 \%$ had 10 or fewer flowers (category 2), $38 \%$ had more than 10 flowers (categories 3 and 4), and $5 \%$ had flowers but it was not possible to determine how many (category $\mathrm{Y}$ ).
Of the 44 trees in agricultural areas $61 \%$ (27 trees) could be assessed with confidence and of these 27 trees $11 \%$ had no flowers, $19 \%$ had 10 or fewer flowers, $63 \%$ had more than 10 flowers and $7 \%$ had flowers but it was not possible to determine the number. Of the 157 trees it was possible to assess in the agricultural and native forest environments $69 \%$ were flowering, such that it is unlikely that flowering was vastly underestimated, given the "steady state' pattern of flowering in G. keule.

In the exotic pine plantation the majority of $G$. keule trees were coppice stools that had resprouted following cutting during establishment of the plantation. The flowering category of all 66 individuals in the pine plantation environment was easily assessed and of these trees $83 \%$ had no flowers $(n=55$ trees), 8 trees had 10 or fewer flowers, and three trees had more than 10 flowers.

All trees were assessed for fruiting and 55 $\%$ of the trees in agricultural sites, $30 \%$ of the trees in native forest and $5 \%$ of trees in pine plantation produced fruit ( $\mathrm{n}=24$ of 44,117 of 388 , and 3 of 55 trees respectively). All of the trees in the three environments that produced fruit could be assessed for flowering and did produce flowers.

As the G. keule trees inside pine plantations showed such low levels of fruiting and flowering the decision was made to exclude these trees from further analysis of flowering, fruiting and pollinator visitation. There was no significant difference between the proportion of trees in each of the 4 flowering categories in the native forest and agricultural environments $\left(\chi^{2}\right.$ test $\mathrm{P}=0.83, \mathrm{n}=$ four flowering categories in each of the two environments). There was a significant difference in fruiting between the native forest and agricultural environments $(\mathrm{t}$ test $\mathrm{P}=0.003, \mathrm{n}=432$ trees assessed for fruiting).

\section{Insect sampling}

In total 34 insects from six families were collected (Table 2). Although little is published on the particular species collected in this study, some of the samples belong to taxa that are potential pollinators, and others are unlikely to be pollinators given the known biology of related taxa. Allograpta hortensis Philippi, Syrphus octomaculatus Walker and $S$. reedi 
Shannon (Syrphidae) were among the most commonly collected species in this study and are potential pollinators. They were trapped during morning (9-10:30), afternoon (12-14:30) and evening (16-17:30) sampling and in both agricultural and native forest sites. Table 2 shows the mean proportion and count of each pollen type found on all specimens of each species. The number of pollen grains of all plant species, including G. keule, found on the syrphids was not significantly different from the number of pollen grains of all plant species found on non-syrphids ( $\mathrm{t}$-test $\mathrm{P}=0.09, \mathrm{n}=34$ insect pollen samples, one from each of 34 insects; 26 Syrphidae and 8 non-Syrphidae). However, the proportion of Gomortega keule pollen found on syrphids was significantly greater than the proportion found on other insects ( $\mathrm{t}$-test $\mathrm{P}=0.019, \mathrm{n}=34$ insect pollen samples, one from each of 34 insects; 26 Syrphidae and 8 non-Syrphidae).

\section{DISCUSSION}

This study, though preliminary in some respects, raises a number of issues of importance for the conservation of Gomortega keule. The G. keule trees inside the exotic pine plantations showed very low levels of flowering and fruiting. This could be due to resource, especially light, limitation inside the plantations, but may also be due to the fact that these individuals were cut when the plantation was established and so were investing in growth rather than reproduction. If the latter possibility is the case, then in the future these trees may produce seed and pollen and make a genetic contribution to the establishment of new cohorts of G. keule. However, processes associated with the establishment of these pine plantations have at least temporarily removed these G. keule individuals from the breeding population of this already rare and endangered species.

A greater proportion of trees in the agricultural areas were producing fruit compared to individuals in the native forest areas. In the agricultural areas $88 \%$ of assessed trees produced flowers and $55 \%$ produced fruit, and in the native forest area $65 \%$ of assessed tree produced flowers and $30 \%$ produced fruit, thus flower production is probably not the limiting factor for fruit production in either environment. The observed differences in fruit production between native forest and agricultural environments may reflect greater efficacy or abundance of pollinators in the agricultural areas, potentially different nutrient, water and light environments, or in the previous year more trees in the agricultural areas may have flowered compared to the native forest areas. Perhaps most importantly, G. keule trees in both agricultural and native forest environments do produce both flowers and

TABLE 2

Numbers of insect species and proportion of plant species' pollen on insects sampled on Gomortega keule flowers in the Maule region of Chile $(\mathrm{n}=$ mean number of grains counted).

Número de especies de insectos y proporciones medias de polen en los insectos capturados en las flores de Gomortega keule en la región de Maule, Chile, $\mathrm{n}=$ número promedio de granos de polen.

\begin{tabular}{|c|c|c|c|c|c|c|}
\hline \multirow[b]{2}{*}{ Taxa } & \multicolumn{3}{|c|}{ Number of individuals } & \multicolumn{3}{|c|}{ Proportion of pollen $\%(\mathrm{n})$} \\
\hline & Forest & Agriculture & Gomortega & Gevuina & Pinus & Other \\
\hline Syrphus octomaculatus (Syrphidae) & 2 & 3 & $42 \%(29)$ & $37 \%(52)$ & $18 \%(18)$ & $3 \%(5)$ \\
\hline Podogritus spp. (Sphecidae) & 0 & 1 & $36 \%(85)$ & $40 \%(94)$ & $23 \%(53)$ & $0 \%(1)$ \\
\hline Allograpta hortensis (Syrphidae) & 12 & 7 & $29 \%(22)$ & $49 \%(72)$ & $16 \%(16)$ & $5 \%(4)$ \\
\hline Syrphus reedi (Syrphidae) & 1 & 1 & $16 \%(37)$ & $74 \%(452)$ & $6 \%(18)$ & $4 \%(4)$ \\
\hline Sapromyza edwardsi (Lauxanidae) & 1 & 0 & $15 \%(17)$ & $69 \%(77)$ & $14 \%(16)$ & $1 \%(1)$ \\
\hline Vespula germanica (Vespidae) & 1 & 2 & $11 \%(28)$ & $80 \%(228)$ & $7 \%(13)$ & $2 \%(7)$ \\
\hline Colletidae & 1 & 0 & $8 \%(31)$ & $83 \%(306)$ & $4 \%(16)$ & $5 \%(17)$ \\
\hline Indipsocus cristatus (Psocidae) & 1 & 0 & $6 \%(52)$ & $92 \%(821)$ & $2 \%(20)$ & $0 \%(4)$ \\
\hline Sapromyza micropyga (Lauxanidae) & 1 & 0 & $6 \%(54)$ & $91 \%(844)$ & $3 \%(24)$ & $1 \%(5)$ \\
\hline
\end{tabular}


fruits, thus the agricultural environment does not appear to limit this part of the species' reproduction. Although some authors have not found differences in seed viability between fragmented and continuous environments for other species (Valdivia et al. 2006, Henríquez 2004), the difficulty experienced in germinating seed of this species means that we have no data on seed germination or seedling survival. However there may be differences between seeds from the two environments at these later stages of reproduction.

Our data show that Gomortega keule is predominantly visited by syrphid flies in late March - early April, and that syrphids carry a greater proportion of $G$. keule pollen than other insects that were collected on the trees. Although some authors suggest that syrphids may be inefficient pollinators, numerous studies have shown that syrphids are important pollinators for a range of species (Schmid 1970, Garcia \& Chacoff 2007, Elam et al. 2007, Cronk 2000, Percy \& Cronk 1997), they are found in most terrestrial habitats (Dziock 2006), and they may be effective through shear frequency of visitation or because of their foraging behaviour and abundance (Westerbergh \& Saura 1994).

Additional evidence for the potential role of syrphids as pollinators of Gomortega keule comes from morphological data. G. keule flowers have stamens in interior and exterior series (Fig. 1). At the base of each of the stamens in the interior series there are two glands which produce small amounts of concentrated nectar (Rodríguez et al. 2001). Small, shiny glands containing low volumes of highly concentrated nectar, either solid on the surface of the nectary or sequestered in tissue (Gilbert 1981), are common in syrphidpollinated flowers (Fleming et al. 2007, Sutherland et al. 2003, Arroyo \& Dafni 1995, Muraoka \& Watanabe 1994, Ivri \& Dafni 1977). Syrphid flies have also been found to have an innate foraging response to visual pollen signals, specifically points of light precisely in the spectral reflectance range of yellow pollen. Therefore, syrphids are more likely to land on a flower with yellow pollencontaining anthers in full display such as $G$. keule (Fig. 1) than on flowers where the anthers and pollen are hidden within the flower (Lunau 2000).
The non-syrphid insect species collected may provide pollination services, and were carrying G. keule pollen on their bodies (Table $2)$, although the taxa to which the insects belong are not known pollinators. Indipsocus cristatus New \& Thornton (Psocidae) is mainly known for eating pollen and foliacious fungi (T New, personal communication, 2005). Members of the Crabronini tribe, to which Podogritus spp. (Sphecidae) belong, are typically solitary predators that prey on Diptera (Evans \& Matthews 2007). The Lauxanidae (Sapromyza edwardsi Malloch and $S$. micropyga Malloch) are known for feeding on decaying leaf litter in forests (S Gaimari, personal communication, 2005). Vespula germanica Fabricius (Vespidae) is likely to be a predator of the other insects found on $G$. keule, although the species also feeds on nectar and pollen (Jandt \& Jeanne 2005).

Insect sampling method has been found in some cases to affect study results. For example, species captured along a vertical gradient, i.e. at various heights above the ground, may or may not vary depending on a number of factors: some studies have reported that insect richness does not vary although species composition does (Vance et al. 2003), that species abundance varies more than species presence (Francese et al. 2008, Ulyshen \& Hanula 2007), and that the amount of variation in species along a vertical gradient depends both on the surrounding vegetation type (Gossner 2009) and on the insect taxa of interest (Wermelinger et al. 2007). More generally it has been found that the trap type significantly affects the insect species captured (Karem et al. 2006). Given the small sample of insects collected, the fact that one trapping method (hand-held nets) was used and that insects were not collected above $5 \mathrm{~m}$, they may represent a particular subset of the species that visit $G$. keule. However all of the insects collected were carrying G. keule pollen on their bodies and among the insects collected there are likely candidates for effective pollinators of G. keule, particularly among the Syrphidae (Table 2).

To our knowledge, little research has been published on the biology of the Syrphidae species we collected. Based on literature on related taxa within the genera and family, these species are likely to be sensitive to landscape 
composition and change. Adult syrphids have been found to respond to landscape composition

(Dziock 2006), including potential barriers to movement such as roads and hedges (Wratten et al. 2003), and changes in habitat quality due to land management, particularly agricultural management (Büchs 2003). Due to the diverse habitat requirements of syrphid larvae, this family as a whole is particularly negatively affected by reductions in the diversity of landuse types. Büchs (2003) suggests that syrphids can function as bioindicators of environmental stress and loss of landscape diversity because of their sensitivity. However, in this study the same species of syrphids were found in both the native forest and agricultural environments, suggesting that the low-intensity agriculture in the study area is not a barrier to movement of these syrphids. This result is supported by genetic markerbased paternity analysis of seeds collected in this study area indicating that G. keule pollen moves successfully between trees in native forest areas and trees in agricultural areas as well as between remnant native forest patches separated by areas of agriculture (Lander 2009).

\section{CONCLUSION}

During the last 25 years a large proportion of the Maulino forest of the central coast of Chile has been replaced with plantations of Pinus radiata (Henríquez 2004) and Eucalyptus spp. and cleared for agriculture. There are fears that this change in habitat types and extent could change patterns of survival and reproduction for many species in the region (Bustamante et al. 2005, FAO 2005, San Martín et al. 1995). Break down of pollination mutualisms is of special concern for conservation as there are implications for fruit production, seed quality, seedling establishment and long term population viability. Rare species with small, scattered populations would be particularly at risk if reproduction broke down and survival was reduced.

This study has found that native forest and local agricultural systems provide habitat where pollinators of Gomortega keule forage and in which G. keule is able to both flower and fruit successfully, but exotic pine plantation does not; suggesting that a landscape made up of a mosaic of different landuse types is not necessarily inimical to the continued reproduction of $G$. keule, but that the combination and types of landuses and intensity of management must be carefully considered. It should be noted that the agriculture in the study area is on a small scale and of low intensity. Other, more intensive industrial types of agriculture could well have different impacts on both the tree and the pollinator community. This is especially true given the known sensitivity of syrphids to landuse type and diversity. Other aspects of population persistence and establishment such as seed dispersal and seedling germination and survival have not been addressed in this study and may also differ between pine plantation, native forest and agricultural environments.

\section{ACKNOWLEDGEMENTS}

We are grateful to The Darwin Initiative (DEFRA) and The Genetics Society for their financial support for this project; Dr. Stephen D. Gaimari (California Department of Food and Agriculture), Dr. James Hogan (University of Oxford Natural History Museum), Dr. Tim New (La Tribe University; Australia), and Dr. F. Christian Thompson (Systematic Entomology Lab USDA) for insect identification, to the Comité Nacional Pro Defensa de la Flora y Fauna (CODEFF), in particular Pedro Garrido Vásquez and Cesar A. Sepulveda for invaluable support during the field work and Franz Arnold for contributions both at the initiation of the project and throughout its progress; La Comisión Nacional del Medio Ambiente (CONAMA), in particular Patricio Olivares for his guidance at the inception of the project and practical support throughout; the Universidad de Talca in particular Dr. José San Martín Acevedo for invaluable contributions as Chilean coordinator of the Darwin Maule project; La Corporación Nacional Forestal (CONAF), Forestal Mininco, Forestal Celco and Forestal Masisa, in particular Mauricio Manriquez, for practical support during the field work and for their kind permission to access their property; Jesús Cordero and John Baker for assistance with 
images, and Fernando Campos-Soto for his hospitality and assistance which made the fieldwork infinitely better than it might have been. Thanks to three anonymous reviewers for comments on an earlier version of this paper.

\section{LITERATURE CITED}

ADRIAENSEN F, JP CHARDON, G DE BLUST, E SWINNEN, S VILLALBA, H GULINCK \& E MATTHYSEN (2003) The application of 'leastcost' modelling as a functional landscape model. Landscape and Urban Planning 64: 233-247.

ARROYO J \& A DAFNI (1995) Variations in habitat, season, flower traits and pollinators in dimorphic

Narcissus tazetta L. (Amaryllidaceae) in Israel. New Phytologist 129: 135-145.

BAWA KS \& R SEIDLER (1998) Natural forest management and conservation of biodiversity in tropical forests. Conservation Biology 12: 46-55.

BÜCHS W (2003) Biodiversity and agri-environmental indicators-general scopes and skills with special reference to the habitat level. Agriculture Ecosystems \& Environment 98: 35-78.

BUSTAMANTE RO, JA SIMONETTI, AA GREZ \& JS MARTÍN (2005) Fragmentación y dinámica de regeneración del bosque maulino: diagnóstico actual y perspectivas futuras In: Smith-Ramírez C, JJ Armesto \& C Valdovinos (eds) Historia, biodiversidad y ecología de los bosques de la Cordillera de la Costa: 555-564. Editorial Universitaria, Santiago, Chile.

CRONK Q (2000) The endemic flora of St Helena. Anthony Nelson, Oswestry, UK. 119 pp.

DZIOCK F (2006) Life-history data in bioindication procedures, using the example of hoverflies (Diptera, Syrphidae) in the Elbe floodplain. International Review of Hydrobiology 91: 341-363.

ELAM DR, CE RIDLEY, K GOODELL \& NC ELLSTRAND (2007) Population size and relatedness affect fitness of a self-incompatible invasive plant. Proceedings of the National Academy of Sciences of the United States of America 104: 549-552.

EVANS HE \& RW MATTHEWS (2007) Notes on the prey and nests of some Australian Crabronini (Hymenoptera: Sphecidae). Australian Journal of Entomology 10: 1-4

FAO (2005) Global Forest Resources Assessment 2005 Progress towards sustainable forest management. FAO Forestry Paper 147. Food and Agriculture Organization of the United Nations, Rome, Italy. $320 \mathrm{pp}$

FLEMING PA, SD HOFMEYR \& SW NICOLSON (2007) Role of insects in the pollination of Acacia nigrescens (Fabaceae). South African Journal of Botany 73: 49-55.

FRANCESE JA, JB OLIVER, I FRASER, DR LANCE, N YOUSEF, AJ SAWYER \& VC MASTRO (2008) Influence of trap placement and design on capture of the emerald ash borer (Coleoptera: Buprestidae). Journal of Economic Entomology 101: 1831-1837.

GARCÍA D \& NP CHACOFF (2007) Scale-dependent effects of habitat fragmentation on hawthorn pollination, frugivory, and seed predation. Conservation Biology 21: 400-411.
GENTRY AH (1974) Flowering phenology and diversity in tropical Bignoniaceae. Biotropica 6: 64-68.

GILBERT F (1981) Foraging ecology of hoverflies: morphology of the mouthparts in relation to feeding on nectar and pollen in some common urban species. Ecological Entomology 6: 245-262.

GOLDBLATT P (1976) Chromosome number in Gomortega keule. Annals of the Missouri Botanical Garden 63: 207-208.

GOSSNER MM (2009) Light intensity affects spatial distribution of Heteroptera in deciduous forests. European Journal of Entomology 106: 241-252.

HECHENLEITNER P, MF GARDNER, PI THOMAS, C ECHEVERRÍA, B ESCOBAR, P BROWNLESS \& C MARTÍNEZ (2005) Plantas Amenazadas del Centro-Sur de Chile Distribución, Conservación y Propagación. Universidad Austral de Chile y Real Jardín Botánico de Edimburgo, Valdivia, Chile. 187 pp.

HENRÍQUEZ CA (2004) Efecto de la fragmentación del hábitat sobre la calidad de las semillas en Lapageria rosea. Revista Chilena de Historia Natural 77: 177-184.

HOUSE SM (1989) Pollen movement to flowering canopies of pistillate individuals of three rain forest tree species in tropical Australia. Australian Journal of Ecology 14: 77-94

IVRI Y \& A DAFNI (1977) The pollination ecology of Epipactis consimilis Don. (Orchidaceae) in Israel. New Phytologist 79: 173-177.

JANDT JM \& RL JEANNE (2005) German yellowjacket (Vespula germanica) foragers use odors inside the nest to find carbohydrate food sources. Ethology 111: 641-651.

JULES ES \& P SHAHANI (2003) A broader ecological context to habitat fragmentation: Why matrix habitat is more important than we thought. Journal of Vegetation Science 14: 459-464.

KAREM J, SA WOODS, F DRUMMOND \& C STUBBS (2006) Sampling native wasps along both vertical and horizontal gradients in the Maine lowbush blueberry landscape. Environmental Entomology 35: 1083-1093

LANDER TA (2009) Landscape genetics of the endangered Chilean tree, Gomortega keule. Plant Sciences. University of Oxford, Oxford. $167 \mathrm{pp}$.

LAVERGNE S, W THUILLER, J MOLINA \& M DEBUSSCHE (2005) Environmental and human factors influencing rare plant local occurrence, extinction and persistence: a 115-year study in the Mediterranean region. Journal of Biogeography 32: 799-811.

LUNAU K (2000) The ecology and evolution of visual pollen signals. Plant Systematic Evolution 222: 89111.

MURAOKA K \& M WATANABE (1994) A preliminary study of nectar production of the field cress, Rorippa indica, in relation to the age of its flowers. Ecological Research 9: 33-36.

MURPHY HT \& J LOVETT-DOUST (2004) Context and connectivity in plant metapopulations and landscape mosaics: does the matrix matter? Oikos 105: 3-14.

MYERS N (1990) The biodiversity challenge: Expanded hot-spots analysis. The Environmentalist 10: 243256.

OLDFIELD S, C LUSTY \& A MACKINVEN (1998) The world list of threatened trees. World Conservation Press, Cambridge, UK. 650 pp

PERCY DM \& QCB CRONK (1997) Conservation in 
relation to mating system in Nesohedyotis arborea (Rubiaceae), a rare endemic tree from St Helena. Biological Conservation 80: 135-145.

RENNER SS, AE SCHWARZBACH \& L LOHMANN (1997) Phylogenetic position and floral function of Siparuna (Siparunaceae: Laurales). International Journal of Plant Sciences 158: S89-S98.

RODRÍGUEZ R \& M QUEZADA (2001) Gomortegaceae. In: Marticorena C \& R Rodríguez (eds) Flora de Chile: 16-18. Universidad de Concepción, Concepción, Chile.

SAKAI S \& T INOUE (1999) A new pollination system: dung-beetle pollination discovered in Orchidantha inouei (Lowiaceae, Zingiberales) in Sarawak, Malaysia. American Journal of Botany 86: 56-61.

SAN MARTÍN J \& C DONOSO (1995) Floristic structure and human impact on the Maulino forest of Chile. In: Armesto JJ, C Villagrán \& MK Arroyo (eds) Ecología de los bosques nativos de Chile: 153-167. Editorial Universitaria, Santiago, Chile.

SAN MARTÍN J \& A SÁNCHEZ (1999) Las comunidades relictas de Gomortega keule (Gomortegaceae, Magnoliopsia) en Chile Central. Anales Jardín Botánico de Madrid 57: 317-326.

SCHMID R (1970) Notes on the reproductive biology of Asterogyne martiana (Palmae). II. Pollination by syrphid flies. Principes 14: 39-49.

SOLTIS P \& D SOLTIS (2004) The origin and deversification of angiosperms. American Journal of Botany 91: 1614-1626.

SUTHERLAND JP, MS SULLIVAN \& GM POPPY (2003) The influence of floral character on the foraging behaviour of the hoverfly, Episyrphus balteatus. Entomología Experimentalis et Applicata 93: 157-164.

ULYSHEN MD \& JL HANULA (2007) A comparison of the beetle (Coleoptera) fauna captured at two heights above the ground in a North American temperate deciduous forest. American Midland Naturalist 158: 260-278.

VALDIVIA CE, JA SIMONETTI \& CA HENRÍQUEZ (2006) Depressed pollination of Lapageria rosea Ruiz et pav. (Philesiaceae) in the fragmented temperate rainforest of Southern South America. Biodiversity and Conservation 15: 1845-1856.

VANCE CC, KR KIRBY, JR MALCOLM \& SM SMITH (2003) Community composition of longhorned beetles (Coleoptera: Cerambycidae) in the canopy and understorey of sugar maple and white pine stands in south-central Ontario. Environmental Entomology 32: 1066-1074.

WERMELINGER B, PF FLUCKIGER, MK OBRIST \& P DUELLI (2007) Horizontal and vertical distribution of saproxylic beetles (Col., Buprestidae, Cerambycidae, Scolytinae) across sections of forest edges. Journal of Applied Entomology 131: 104114.

WESTERBERGH A \& A SAURA (1994) Gene flow and pollinator behavior in Silene dioica populations. Oikos 71: 215-224.

WODEHOUSE R (1935) Pollen grains. McGraw-Hill Book Co. (Hafner Reprint, 1959), New York. 574 pp.

WRATTEN SD, MH BOWIE, JM HICKMAN, AM EVANS, JR SEDCOLE \& JM TYLIANAKIS (2003) Field boundaries as barriers to movement of hover flies (Diptera: Syrphidae) in cultivated land. Oecologia 134: 605-611.

ZANIS MJ, PS SOLTIS, YL QIU, E ZIMMER \& DE SOLTIS (2003) Phylogenetic analyses and perianth evolution in basal angiosperms. Annals of the Missouri Botanical Garden 90: 129-150.

Associate Editor: Rosanna Ginocchio

Received May 5, 2009; accepted July 31, 2009 